\title{
IRONIA E HUMOR NAS ELEGIAS DE PROPÉRCIO
}

\author{
ZELIA DE ALMEIDA CARDOSO* \\ Faculdade de Filosofia, Letras e Ciências Humanas \\ Universidade de São Paulo
}

\begin{abstract}
RESUMO: Procuramos mostrar, neste artigo, alguns traços de ironia e humor nas elegias de Propércio, revelados no tratamento dado por vezes ao amor, à doença, à morte, à religião e ao nacionalismo. A ironia bemhumorada, vista como uma das características do gênero elegíaco, confirma a proposta, segundo a qual a elegia é um poema artificial, elaborado de acordo com cânones estéticos pré-estabelecidos.
\end{abstract}

PALAVRAS-CHAVE: Propércio; elegias; ironia; humor.

Quando, em 1983, Paul Veyne publicou Lélégie érotique romaine, os estudiosos da poesia latina se defrontaram com uma postura original em face de um gênero poético que costumava ser avaliado de uma ótica bastante diferente. Até então a maioria dos críticos, comentadores e historiadores da literatura via na elegia romana a concretização de uma poesia confessional na qual o poeta se projetava deixando extravasar-se o subjetivismo, os sentimentos, a paixão não raro incompreendida, o sofrimento, enfim. ${ }^{1}$

Veyne adotou uma posição diferente. Para ele, a elegia, "é uma das formas de arte mais sofisticadas de toda a história da literatura", não existindo muitas outras "cuja natureza tenha sido mais desconhecida" (Veyne, 1985, p. 9). O poeta elegíaco é um artífice que trabalha os textos de acordo com os cânones poéticos vigentes e que, por usar a primeira pessoa e criar a personagem de um "eu-poético" ao qual dá seu próprio nome, foi considerado como um artista sincero que disse

\footnotetext{
* Professora Titular de Língua e Literatura Latina do Departamento de Letras Clássicas e Vernáculas da FFLCH-USP.

1 Vejam-se, por exemplo, as observações de Rostagni (1939, p. 367-370) a respeito do caráter autobiográfico da elegia latina.
} 
exatamente o que pensava e fazia, espelhando-se nos textos por ele compostos. Os dados "biográficos" de Tibulo, Propércio e Ovídio, apresentados por "biógrafos" desses poetas, foram extraídos muitas vezes do corpo dos poemas.

Veyne procurou desfazer esse mito, mostrando que a elegia é uma modalidade poética artificial, elaborada; o poeta elegíaco se utiliza das regras do gênero, criando o "ambiente elegíaco", provocando equívocos deliberadamente por meio da "ironia elegíaca", ${ }^{2}$ dizendo o que não é com humour e fazendo valer o chamado "jogo elegíaco".

Reportando-se a Calímaco, um dos inspiradores da elegia latina, Veyne se pergunta a si próprio sobre a proveniência da irony do poeta e, ao responder, procura mostrar que a poesia calimaqueana é obra de um artista "que brinca com a particularidade que um texto possui de poder reduzir-se à sua significação literal que sempre pode apresentar-se como independente". Para Veyne, Calímaco "fundou uma estética sobre um fato semiótico: a independência da significação literal", dedicando-se ao exercício de equilibrismo e, portanto, de graça, compondo textos que, "longe de serem um espelho da realidade", são equívocos, e valendo-se de uma escritura que não se basta, uma vez que não exprime nada..." (1985, p. 34-35).

Discípulo de Calímaco e produto de uma época especial em que os antigos valores e as velhas crenças são postos em cheque, Propércio também se utiliza da ironia e da brincadeira velada para questioná-los. E o faz por meio de elegias (fallax opus, segundo suas palavras ${ }^{3}$ ), nas quais, tratando de questões como o amor, a fidelidade, a morte, os deuses, a religião, a guerra e o nacionalismo, exprime idéias de forma ambígua, de modo a proporcionar aos leitores uma variedade de "leituras" que corresponderão a diversas interpretações.

2 Curiosamente, antecipando-se em muito ao que viria depois, M. Patin (1900, p. 148), na virada do século XIX para o século XX, se referiu à presença de elementos irônicos nas elegias de Propércio e as considerou como "um pouco de sangue novo no meio da imitação e do servilismo do momento" (tradução de minha responsabilidade).

3 Na elegia IV, 1, 135, um adivinho criado pelo poeta dialoga com ele, procura dissuadilo de compor poesia laudatória e lhe relembra a missão que tem: At tu, finge elegos, fallax opus - haec tua castra! (Quanto a ti, compõe elegias, obra enganosa - este será teu campo de batalha). Os textos latinos citados no presente artigo são extraídos da edição das Elegias, publicada pela Société d'Édition Les Belles Lettres, em 1929, e reeditada numerosas vezes (Properce, 1970). As traduções são de minha responsabilidade. 
O amor é o grande tema properciano. Das noventa e duas elegias que compôs, setenta e três exploram o amor; em trinta o nome de Cíntia aparece explicitamente; em muitas outras, embora tal nome não seja mencionado, não há dúvidas de que seja ela o objeto do poema. Esse fato leva a uma indagação preliminar: quem é, ou quem era Cíntia? Há quase dois mil anos vêm sendo feitas elucubrações com a finalidade de deslindar-se a questão, mas, como só conhecemos a famosa mulher por meio de uma obra literária, o mais razoável seria considerar a "amada" do poeta - ou melhor, do "eu-poético" que aparece nos textos, falando em primeira pessoa - como uma personagem meramente ficcional, uma criação literária a exemplo de tantas outras.

De Cíntia temos o "retrato" feminino mais completo e complexo de toda a poesia latina (Cardoso, 2003, p. 261-285). As outras mulheres que figuram nos poemas produzidos em Roma se mostram singelas em seus contornos diante da profusão de dados que compõem a personagem modelada por Propércio. Dessa forma, responder à questão "Quem é Cíntia?" exige uma leitura acurada não só dos trinta poemas em que é citado o nome da "musa inspiradora" do poeta mas também dos outros que se referem indiscutivelmente a ela, mesmo sem nomeá-la. Diante dessa mulher, desenhada com enorme riqueza de atributos, o amante se prosterna como servidor fiel e apaixonado. Mas a leitura atenta dos poemas revela, pouco a pouco, a polivalência de sentido, as ambigüidades, as contradições, a brincadeira literária que configura o jogo elegíaco, a ironia properciana, enfim.

Tomemos alguns textos como exemplo dessas ambigüidades e contradições.

Na primeira elegia do primeiro livro - que, cronologicamente, não deve ser a primeira da coletânea ${ }^{4}$, o primeiro dístico se abre com o nome de Cíntia:

Cynthia prima suis miserum me cepit ocellis contactum nullis ante cupidinibus (Prop. I, 1, 1-2)

Cíntia foi a primeira que me conquistou, com seus belos olhos, a mim, infeliz, não antes tocado por nenhum desejo.

Segundo se depreende desse texto - e de outros que se espalham pelos quatro livros que compõem a obra completa -, foi com Cíntia que o "eu-poético" apren-

4 Veja-se a observação de D. Paganelli, que estabeleceu e traduziu o texto das elegias na edição supracitada, ao apresentar o resumo da elegia I (Properce, 1970, p. 4). 
deu a amar e foi somente a ela que ele amou. No entanto, na elegia III, 15, ao dirigir-se à amada, censurando o ciúme que ela nutre pela escrava Licina, ele diz:

Vt mihi praetexti pudor est uelatus amictu et data libertas noscere amoris iter (Prop. III, 15, 3-4)

Quando meu pudor era ainda velado pela toga pretexta, foi-me dada a liberdade de conhecer o caminho do amor;

refere-se, então, a Licina, que, com sua habilidade, sem ser comprada por dinheiro ou mimos, ${ }^{5} \mathrm{o}$ iniciou nas práticas amorosas:

Illa rudis animos per noctes conscia primas imbuit, heu! nullis capta Lycinna datis (III, 15, 5-6)

Competente, ela instruiu um espírito ignorante, durante as primeiras noites: Licina, ai de mim! a que não foi conquistada por presentes.

Esse fato havia ocorrido três anos antes, segundo o texto, e, embora o adolescente, como diz o poeta, não tivesse trocado com a escrava nem sequer dez palavras, passara a conhecer o amoris iter.

A contradição que existe entre os dois poemas se configura como um traço do humor properciano. Cíntia não fora a primeira a provocar o desejo do jovem. Foi a primeira, sim, segundo se depreende de suas palavras - se é que podem ser consideradas confiáveis, mesmo num plano diegético -, a torná-lo escravo do amor, enlouquecido pela paixão e desconfiado da proteção dos deuses:

Tum mihi constantis deiecit lumina fastus, et caput impositis pressit Amor pedibus (I, 1, 3-4)

Amor, então, me fez baixar a firme altivez dos olhos e comprimiu minha cabeça, pisando-a com os pés.

5 A referência ao desinteresse de Licina por presentes remete à elegia II, 16 em que o "eupoético" se lamenta da infidelidade de Cíntia, cujo antigo amante retornara da Ilíria; em sua lamentação ele fala que honrarias políticas não interessam à jovem, desejosa de jóias e tecidos finos; interessa-lhe o peso da bolsa do homem que a procura. 
Há muitas ambigüidades no texto da elegia I, 1 . O leitor se vê diante de um quebra-cabeças e, se inicialmente pode até sentir certa irritação, decorrente das obscuridades, acaba por entender o jogo e se diverte em decifrá-lo. Quando o poeta diz, por exemplo, que Amor o ensinou a odiar as moças castas (me docuit castas odisse puellas - I, 1,5), não se sabe se ele está referindo-se a Cíntia, que é casta e não o aceita como amante, ou às outras moças que são castas enquanto Cíntia, a preferida, não o é. Quando emprega o adjetivo improbus (ímprobo, desavergonhado, indiferente às leis), em improbus et nullo uiuere consilio (I, 1, 6), não se sabe se o emprega como um aposto de Amor - Amor [...] improbus, o "ímprobo" Amor - ou como um nominativo qualificativo vinculado a uiuere - improbus [...] uiuere ("O ímprobo Amor [me ensinou] a viver sem nenhuma sensatez" ou "Amor [me ensinou] a viver como um ímprobo, sem nenhuma sensatez" ${ }^{\prime \prime}$. Ambas as soluções são possíveis e a tradução desfaz a ambigüidade do jogo elegíaco que permite a duplicidade ou multiplicidade de leituras; a tomada de posição congela o pensamento, elimina a possibilidade de encarar o poema como um objeto tridimensional que pode ser visto de vários ângulos.

E a elegia continua, cheia de apóstrofes, que confundem o leitor. Quem é o destinatário do poema? Tulo, a quem é narrada a historieta de Milanião, inserida no texto meio fora de propósito, como uma prática alexandrina bastante usual (I, $1,9-16)$ ? Ou as pessoas, designadas por uos ("vós", "vocês"), às quais o "poeta" se dirige (I, 1, 19-38)? Vos representa um grupo de pessoas ou dois? Ou três? O poeta invoca inicialmente um suposto primeiro grupo, o dos que conhecem fórmulas mágicas e sabem controlar o amor, fazendo uma oposição - marcada por at - entre eles e ele próprio, o "eu-poético", incapaz de conduzir-se de forma racional:

At uos, deductae quibus est fallacia lunae

et labor in magicis sacra piare focis

en agedum domina mentem conuertite nostrae

et facite illa meo palleat ore magis.

Tunc ego crediderim uobis et sidera et amnis

posse Cytaines ducere carminibus (I, 1, 19-24)

Mas vocês, que dominam os enganos de uma lua dócil

e a arte de celebrar sacrifícios em altares mágicos,

6 Ernout e Thomas (1953. p. 13) se referem a esse tipo de construção. 
eia, vamos, convertam a mente de minha amada e façam que ela empalideça mais do que meu rosto.

Então eu acreditaria em vocês, e que astros e rios vocês podem dominar com os encantamentos da Cita.

Em seguida, como a indicar um segundo grupo de destinatários - daí o uso da aproximativa et -, o poeta diz Et uos ("Quanto a vocês" - os que procuram chamá-lo à a razão), interpelando-os e considerando-os amici ("amigos"):

Et uos, qui sero lapsum reuocatis, amici, quaerite non sani pectoris auxilia (I, 1, 25-26)

Quanto a vocês, amigos, que tarde procuram erguer quem caiu, busquem auxílio para um peito doente.

Finalmente ele se dirige a um terceiro grupo, genérico, designado também por uos, o grupo dos protegidos dos deuses, que compartilham de amores tranqüilos e bem correspondidos. Seria um grupo? Ou um casal, um par de amantes?

Vos remanete, quibus facili deus annuit aure, sitis et in tuto semper amore pares (I, 1, 31-32)

Vocês, que um deus atendeu com ouvido favorável, perseverem, e que fiquem sempre juntos, num amor seguro.

São realmente muitas as ambigüidades. Mas passemos adiante. Vejamos a elegia I, 2, na qual o poeta recomenda a Cíntia que deixe de lado os adornos artificiais porque ela é suficientemente bela para poder dispensá-los: "Tem tudo que Vênus aprova". ' A elegia é parodiada e satirizada em IV, 5, na qual estão inseridos $^{8}$ versos da I, 2, num contexto mordaz, em que o poeta diz ironicamente o

7 ... omnia quaeque Venus [... ] probat - I, 2, 30. Os atributos de Cíntia vão ser decantados um a um no correr das elegias - os cabelos (II, 2, 5; II, 3, 13), o rosto alvo (I, 4, 13; II, 3, 10-12), os olhos brilhantes (II ,3, 14), as mãos alongadas e níveas (II, 2, 5; III, 6, 12), os dedos ebúrneos (II, 1, 9), as unhas formosas (III, 8, 6), os seios perfeitos (II, 15, 21), as graças que se ocultam sob as vestes (I, 4, 13-14).

8 Os versos Quid iunat ornato procedere, uita, capillo/ et tenuis Coa ueste mouere sinus (I, 2, 1-2) são repetidos em IV 5, 55-56, quando o poeta, em tom sarcasticamente irônico, 
oposto do que antes dissera. Quanto aos "dons de Vênus", tão amplamente mencionados nesse texto e em muitos outros, são eles subestimados na última elegia do livro III, quando o amante fiel se despede da amada volúvel e perjura, referindo-se à velhice de Cíntia que chegará em breve, aos cabelos brancos que ela arrancará pelas raízes e às rugas que o espelho lhe mostrará. O último verso é incisivo e cruel:

\section{Euentum formae disce timere tuae (III, 25, 18)}

Aprende a temer o fim de tua formosura!

Na elegia I, 3, voltamos a encontrar o humor properciano que se expressa por contradições. A fides do amante, a lealdade como seu apanágio maior, é mencionada a todo momento, no texto dos poemas. ${ }^{9}$ Cíntia, para ele, é o seu primeiro e último amor, ${ }^{10}$ é a única, ${ }^{11}$ a fonte de inspiração, ${ }^{12}$ a vida, ${ }^{13}$ a luz,,${ }^{14}$ tudo. Ela, em contraposição, é usualmente apresentada como uma mulher infiel, pérfida, mentirosa. ${ }^{15}$ Pois bem, na elegia I, 3, o relato nos surpreende. No poema, composto de forma narrativa, o eu-narrador conta o que ocorrera numa noite em que fora visitar a amada. Chegara muito tarde à casa de Cíntia, bêbado, com passos vacilantes, e a encontrara adormecida; acariciou seus cabelos, mas, embora excitado, não ousou ir além por temer uma explosão de raiva. Um raio de luar, no entanto, a despertou e ela se queixou do amante que a obrigara a permanecer só, por longas horas, esperando-o em vão; procurara distrair-se fiando e tocando lira enquanto

aconselha a mulher a só se importar com o ouro que vem dos amantes e não com os poemas que as louvam.

9 Vejam-se, p.e., I, 8, 21; 18, 11-12; II, 6, 42; 17, 17-18; 21,19-20.

10 Cynthia prima fuit, Cynthia finis erit (I, 12, 20).

11 Em I, 11, 23, o poeta diz: "Tu mihi sola domus, tu, Cynthia, sola parentes/ omnia tu nostrae tempora laetitiae".

12 A elegia II, 1, 1-16 se abre com uma exaltação à Cíntia, de acordo com a qual ela substitui Calíope e Apolo como "deusa inspiradora"; prossegue com o elogio a seus dotes físicos, cada um dos quais poderia operar como motivo poético.

13 Nas elegias I, 2, 1; 8, 22; II, 3, 23; 5, 18; 20, 11; 24, 29; 26, 1; 30, 14, o poeta emprega o epíteto mea uita, ao dirigir-se a Cíntia.

14 Nas elegias II, 14, 29; 28, 59; 29, 1, o epíteto empregado é mea lux.

15 Vejam-se, como exemplo, as elegias I, 15, 24; II, 6, 6; 9. 
ele se divertia com outras mulheres... Como o jovem não contesta, a palavra final é dela e as imagens se invertem. Ela é a mulher fiel e ele o perjuro.

A mesma reclamação pode ser observada na elegia II, 29. O amante chega à casa da amada ao raiar da manhã, conta-lhe uma história fantástica, de pequenos amores que o assaltaram durante a noite, e é duramente censurado por ela. Cíntia põe em confronto sua própria fidelidade e a infidelidade do amante, recusa seus beijos, repele-o e se afasta dele.

Na elegia IV, 7, a situação se repete mais uma vez. Nessa elegia Propércio descreve a aparição do espírito de Cíntia, que morrera e acabava de ser incinerada. Ao voltar dos funerais da amada o amante se deita e a vê, como sombra, perto do leito. A descrição da jovem morta poderia parecer tocante, se dela não se extravasasse um possível tom de brincadeira:

Eosdem habuit secum, quibus est elata capillis

eosdem oculos; lateri uestis adusta fuit

et solitum digito beryllon adederat ignis, summa Lethaeus trinerat ora liquor, spirantisque animos et uocem misit, at illi pollicibus fragiles increpuere manus (IV, 7, 7-12)

Tinha os mesmos cabelos, com que foi levada, os mesmos olhos; a veste estava queimada, de um lado; o fogo atingira o berilo que ela usava sempre em seu dedo; a água do Letes desgastara seus lábios; falou como se estivesse emitindo um sopro, mas sua frágeis mãos crepitavam nas juntas.

As palavras de Cíntia o recriminam pelas omissões: ele se entrega ao sono, já a esqueceu, ninguém o viu chorar, ele não a chamou pelo nome durante os funerais, não verteu perfumes sobre a pira, não lhe ofereceu as últimas flores. Ela cobra seus juramentos falsos, acusa-o de perfídia, refere-se a outra mulher que lhe merece as boas graças e só se consola por saber que, apesar de tudo, ele morrerá em breve e será então só seu: e, numa tirada macabramente humorística, ela fala dos ossos de ambos que se misturarão e se esfregarão conjuntamente por toda a eternidade. ${ }^{16}$

16 Os versos 93-94 da elegia IV, 7 (Nunc te possideant aliae: mox sola tenebo;/ mecum eris et mixtis ossibus ossa teram) foram objeto de discordância entre os estudiosos do poeta. 
Esses episódios levam-nos a discutir a personalidade do "eu" properciano. Quem é ele, afinal? Um amante fiel que cumpre os juramentos e morre por seu amor ou um homem libertino e falso que trai as próprias palavras e não vacila em mentir?

No passado, alguns dos comentadores da obra de Propércio fizeram referências a certas incoerências na composição das figuras, considerando-as como uma das falhas do poeta. Chegamos a defendê-lo em certa ocasião (Cardoso, 1984, p. 95), lembrando que a incoerência mencionada é a "incoerência coerente" de que nos fala Aristóteles (Poet. XV, 86), ao lembrar as qualidades que devem caracterizar a construção da personagem: "Ainda que a personagem a representar não seja coerente nas ações, é necessário, todavia, que ela seja coerentemente incoerente". Em nossa defesa dizíamos que o "eu-poético" das elegias seria incoerente e contraditório por ser configurado como um jovem que reagia conforme as circunstâncias e as oscilações de sua vida amorosa. Hoje revemos nossa posição e consideramos essa incoerência como parte do jogo elegíaco, do humour properciano.

Tal "humor" se revela de forma evidente nas elegias III, 8 e IV, 8, que apresentam alguns pontos de contato. Em ambas Propércio relata brigas com a amada que haviam ocorrido em noites anteriores. Na elegia III, 8, a narrativa é curta e opera apenas como pretexto para considerações sobre a delícia que é a violência no amor. Para introduzir suas idéias, o poeta fala de forma jocosa do que ocorrera na véspera, quando a amada (Cíntia?), sob a ação da bebida, o injuriara verbalmente, virara a mesa e lhe atirara no rosto taças cheias de vinho ${ }^{17}$ - para ele, sinais infalíveis de uma grande paixão. Na IV, 8, como se estivesse trabalhando numa sátira, o poeta amplia o relato e o recheia de novos ingredientes. Cíntia e ele haviam estado numa taberna de onde ela saiu, após uma discussão, em companhia de um jovem afeminado. Para vingar-se, ele procura duas prostitutas e planeja uma noite de amor a três. Vênus, porém, o abandona e ele se sente completamente impotente diante das duas mulheres que procuram excitá-lo a todo preço:

Enquanto Grimal (1963) vê nesse contato de ossos pela noite eterna uma redução do amor à pureza essencial, uma realização plena da fides, June W. Allison (1980, p. 170. 173) considera o dístico particularmente erótico, lembrando que os verbos misceo e tero, ali presentes, usualmente conotam atividade sexual. Cf. Cardoso, 1984, p. 114.

17 Dulcis ad hesternas fuerat mihi rixa lucernas/ uocis et insanae tot maledicta tuae./ Cur furibunda mero mensam propellis et in me/ proicis insana cymbia plena manu? ( III, 8, 1-4). 
Cantabant surdo, nudabant pectora caeco;

Lanuuii ad portas, ei mihi, solus eram (IV, 8, 47-48)

Elas cantavam para um surdo, desnudavam os seios para um cego; eu estava só, ai de mim!, junto às portas de Lanúvio.

Nesse momento Cíntia retorna, agride as prostitutas, arranhando-as, arrancando-lhes cabelos e rasgando-lhes as vestes, estapeia o amante com o dorso da mão fazendo-lhe a boca sangrar, morde-o, e só faz as pazes e se entrega ao amor depois de o jovem jurar-lhe que aceita suas regras de vida.

Impossível deixar de rir diante dessas "brincadeiras" de Propércio!

Passemos adiante e analisemos mais um caso curioso, no conjunto dos poemas: a elegia II, 28, que Paganelli apresenta como bipartida (Properce, 1970, p. 73-75).

O poema fala de uma enfermidade da amada e se abre com uma invocação do amante a Júpiter, pedindo-lhe misericórdia para com ela:

Iuppiter, affectae tandem miserere puellae (II, 28, 1)

Júpiter, tem ao menos compaixão de uma jovem doente!

Mas a irreverência, num tom jocoso, se manifesta na constatação por ele feita no pentâmetro que completa o dístico:

Tam formosa tuum mortua crimen erit (II, 28, 2)

Será um crime de tua parte a morte de uma mulher tão bela.

Em seguida, vem uma espécie de explicação "científica" para a doença da beldade, o que reduz a "responsabilidade" do deus:

Venit enim tempus, quo torridus aestuat aer incipit et sicco feruere terra Cane (II, 28, 3-4)

É verdade que chegou o tempo em que o ar tórrido queima e a terra começa a ferver sob a canícula seca. 
A explicação, porém, também é discutida:

Sed non tanto ardoris culpa est neque crimina caeli quam totiens sanctos non habuisse deos.

Hoc perdit miseras, hoc perdidit ante puellas: quicquid iurarunt, uentus et unda rapit (II, 28, 5-8)

Mas a culpa não é tanto do calor e da maldade do céu, quanto de não se ter levado em conta tantas vezes, a santidade dos deuses.

É o que destrói as infelizes; foi o que antes destruiu outras mulheres: todos os juramentos que fizeram o vento e o mar levaram.

A "responsabilidade" pela doença da amada se dividiu, portanto, em três, gerando a dúvida: a culpa é de Júpiter, do calor que traz as febres ou da própria jovem que jurou pelos deuses, tantas vezes, em vão? Há, ainda, uma quarta alternativa: é possível que a amada, sendo tão bela, tenha despertado o ciúme de Vênus, ou o ódio de Juno, cujos templos quiçá tivessem sido desdenhados; ou o de Palas, cuja beleza talvez tivesse sido menosprezada. E o poeta chega a uma conclusão em que se vislumbra ironia e brincadeira: a culpa é das moças que falam demais ou são demasiadamente belas; a língua e a formosura causaram a doença da amada. ${ }^{18}$

Passa então a "consolá-la" e a "consolar-se" a si próprio lembrando tantas mulheres lindas que sofreram e foram recompensadas: se ela morrer, o dia de seus funerais será um dia de glória, pois que ela se misturará às belas heroínas mortas e, entre todas será a mais bonita. ${ }^{19}$

Aqui se inicia a segunda parte do poema, segundo a divisão de Paganelli. $\mathrm{O}$ poeta se refere a sinais mágicos que anunciam a morte iminente da amada; fala de sua própria morte que se juntará à da jovem, se ela morrer; invoca Júpiter e Perséfone; vale-se de lugares-comuns filosóficos lembrando que a beleza não é eterna, que a felicidade não dura para sempre e que cedo ou tarde todos morrem. E depois de tudo isso, no penúltimo dístico, diz intempestivamente que a amada se restabeleceu:

18 Semper, formosae, non nostis parcere uerbis./ Hoc tibi lingua nocens, hoc tibi forma dedit (II, 28, 13-14).

19 ... et tibi Maeonias inter heroidas omnis/ primus erit nulla non tribuente locus (II, 28, 29-30). 
Tu quoniam es, mea lux, magno dimissa periclo... (II, 28, 59)

Uma vez que escapaste de um grande perigo, minha luz...

Ela deverá, portanto, pagar promessas feitas a Diana, participando de coros sagrados, a Ísis, oferecendo-lhe noites de vigília, passadas fora de casa, e ao próprio amante, concedendo-lhe dez noitadas de amor - ele se coloca a si mesmo no mesmo plano das divindades.

Aparentemente o poema termina aí, mas é muito comum, em Propércio, a retomada de um assunto, explorado num poema, em textos consecutivos ou próximos. È o que aparentemente ocorre nas elegias II, 32 e II, 33, quando, dirigindo-se agora nominalmente a Cíntia, o poeta parece retomar o fio interrompido ao final da II, 28. Na elegia II, 32, ele censura a amada por ter participado dos rituais em honra de Trívia; todos a viram, segundo ele, no bosque da deusa, segurando um archote aceso. Ora, o bosque de Trívia nada mais é que o bosque de Diana, em Nemi, e Cíntia, participando do ritual, pagara a promessa anunciada na elegia II, 28. Acontece que esse ritual, mencionado por Frazer, deveria consistir numa espécie de procissão de caráter primitivo da qual participavam devotas que, ao final da cerimônia, se entregavam a um ato coletivo de prostituição. ${ }^{20}$ Daí a indignação do poeta que, a fim de preparar o terreno para a censura, critica a amada por suas escapadas clandestinas e lamenta a infidelidade de Cíntia que provoca murmúrios entre os romanos.

Na elegia II, 33, o amante se queixa porque Cíntia consagrara dez noites a Ísis, cumprindo a segunda promessa feita na II, 28. Essas noites de castidade foram roubadas ao amor. E Propércio amaldiçoa o culto de Ísis que se alastrava em Roma, ridicularizando a deusa que, sob o nome de Io, fora transformada em vaca pelo ciúme de Juno. É a brincadeira do poeta, disfarçada em incoerência, o tratamento dos valores religiosos de forma irônica e jocosa.

Há inúmeras referências a deuses e deusas nas elegias; o emprego da mitologia chega a ser abusivo, mas é um emprego artificial. Estudando os elementos

20 Cf. Frazer,1933, Cap. I. O autor faz referências ao culto de Diana Nemorensis, em Nemi, considerado por ele como vestígio de uma época de barbárie, em virtude de uma das características que o definiam: o sacrifício cruento do sacerdote da deusa. A festa anual de Diana era realizada em agosto, quando mulheres e jovens se dirigiam ao templo com tochas acesas e participavam de cerimônias purificadoras e propiciatórias. Presume-se que houvesse oferendas e entre elas o sacrifício ritual da honra. 
mitológicos em Propércio, Jean-Paul Boucher (1980, p. 227) lembra que embora a mitologia tivesse estado presente na poesia latina de todos os tempos, sendo, portanto, um recurso poético usual, em Propércio o emprego é bastante peculiar. $\mathrm{O}$ relato mitológico praticamente desaparece, ${ }^{21}$ cedendo lugar às alusões mitológicas, aos exempla, às comparações, ao uso metonímico dos nomes divinos. Os deuses deixam de ser apresentados como objetos de culto e chegam a ser criticados veladamente ou às claras.

Propércio faz também muitas referências a práticas religiosas em suas elegias, principalmente às divinatórias, tão comuns em Roma, ${ }^{22}$ mas sempre num tom especial que dá oportunidade a duas suposições: ou que o poeta, a exemplo de outros intelectuais da época, não dava crédito a elas, ou que, ao ironizar um tema sério, estaria identificando-se com os princípios neotéricos e revelando uma atitude própria de quem trabalha com o mundo elegíaco.

Ao falar de adivinhação e ao mencionar adivinhos, áugures e arúspices, Propércio sempre emprega uma linguagem revestida de tom irônico que, por vezes, atinge as raias do jocoso. A brincadeira e a ironia, nas referências à adivinhação, tratadas de forma esporádica em poemas dos livros I, II e III, ${ }^{23}$ se evidenciam com nitidez na complexa e discutida peça de abertura do quarto livro. Sobre ela, portanto, fazemos algumas considerações.

A elegia IV,1 é a mais longa de toda a coletânea - tem cento e cinqüenta versos, enquanto a grande maioria dos textos não chega a cinqüenta - e se compõe de dois monólogos justapostos. A própria composição já acena para uma intencionalidade particular.

O primeiro monólogo é recitado por um poeta, a quem o autor confere seu próprio nome, conforme práxis da poesia elegíaca, projetando-se na personagem, por artifício poético. O "Propércio" fictício acompanha um adivinho babilônico

21 Nos três primeiros livros apenas as elegias I, 20 e III, 15 apresentam relatos mitológicos, a primeira ocupando-se da morte de Hilas, a segunda da de Dirce. São relatos exemplares que ilustram, de forma "didática", conselhos que estão sendo dados a destinatários dos textos.

22 Em dois artigos citados na bibliografia, fazemos um estudo pormenorizado sobre o enfoque da adivinhação nas elegias de Propércio (Cardoso, 1991, p. 163-181; Cardoso, 1993, p. 140-143).

23 Vejam-se, por exemplo, as elegias I, 9, 5-8; II, 17, 1-4; 21, 3-6; 28B, 35-42; 58-59; III, 8, 17-18. 
em um passeio por Roma e lhe apresenta os pontos mais importantes da cidade. Durante essa apresentação faz numerosas alusões à história romana.

A fala do poeta-cicerone é perpassada de referências a práticas divinatórias. Mesmo quando se refere à cidade moderna, ele menciona tais práticas a todo momento, provavelmente para exibir ao visitante sua familiaridade com a adivinhação. Logo no início do texto, após ter feito comentários sobre os principais edifícios e locais paisagísticos visitados - o templo de Apolo, a rocha Tarpéia, o templo de Júpiter, a Cúria, os teatros, os subúrbios - lembra Alba Longa, que, conforme Virgílio, ${ }^{24}$ havia sido fundada depois do reconhecimento de um prognóstico. Propércio alude ao fenômeno, ressaltando a questão do augúrio:

Et stetit Alba potens, albae suis omine nata (IV, 1, 35)

Ergueu-se, então, Alba potente, nascida do presságio da porca branca.

Falando, em seguida, da chegada dos troianos à praia itálica, também em obediência a auspícios favoráveis, neles insiste empregando, para designá-los, a palavra auis, rica em conotações específicas e evocadora da idéia dos avisos obtidos pela interpretação do vôo dos pássaros:

huc quali uecta est Dardana puppis aue (IV, 1, 40)

para cá, sob que augúrio! ${ }^{25}$ foi trazido o barco dardânio.

Relembrando, em seguida, a prenunciada fuga de Enéias, as chamas que, segundo os prognósticos, haviam respeitado o herói (vv. 46-49), as palavras da trêmula Sibila do Averno (49), os auspícios que Rômulo tomara no alto do Aventino (50) e as previsões de Cassandra, durante a guerra de Tróia (51-52), parece querer demonstrar que as adivinhações pontearam a história romana, desde o início, e que ele as conhecia muito bem.

A linguagem utilizada pelo Propércio-personagem em todo esse trecho é bastante hermética e ambígua, apresentando um tom oracular e assemelhando-se,

24 Cf. En. VIII, 43-44. Virgílio se refere ao prognóstico segundo o qual os troianos deveriam fundar uma cidade no local em que encontrassem uma porca branca amamentando dez filhotes.

25 Observe-se que, em latim, auis e augurium têm a mesma raiz significativa. 
portanto, à dos adivinhos profissionais. Depois de relembrar o passado, o "poeta" fala do futuro e de sua pretensão de cantar a glória de Roma. Invoca então a cidade, para que ela o favoreça (67), pede presságios bons a seus concidadãos (68) e "prediz" o temário dessa nova poesia: celebrará as tradições sagradas de Roma, os monumentos religiosos e os nomes de locais importantes (69-70).

Terminado o primeiro monólogo, Horos, o adivinho visitante, assume a palavra, procurando pontificar, de maneira magistral. Ao iniciar a exposição, dirige-se ao poeta e emprega um tom repassado de censura:

Quo ruis imprudens, uage, dicere fata, Properti?

non sunt a dextro condita fila colo (IV, 1, 71-72)

Para onde te precipitas imprudente, louco Propércio, a predizer o destino? Teus fios não foram tramados em roca propícia.

O tom de advertência mostra que o poeta está caminhando em terreno desconhecido e que não deve envolver-se com profecias. Quem detém o poder de ver o futuro é ele, Horos, filho de Órops, da Babilônia, descendente de Árquitas e de Cônon. Ele é o verdadeiro vate, capaz de movimentar os sinais numa esfera de bronze e conhecedor da verdade contida nos livros (74-80).

Mostra, então, numa espécie de preâmbulo, que os deuses - como as mulheres fáceis, diríamos - se deixam comprar por meio do ouro e exalta a ciência que domina: conhece os sinais do Zodíaco, interpreta o curso do sol e a órbita dos planetas e sabe explicar a mensagem dos astros (81-86). Em seguida, dispondo-se a fazer "revelações", o adivinho diz o que todos sabem de sobejo, retomando o que o "poeta" acabara de dizer e apresentando o passado como futuro: Tróia cairá e renascerá em Roma (87). Discorre, a partir desse momento, sobre assuntos absolutamente particulares e considerados obscuros ou enigmáticos por alguns críticos: fala de uma certa Árria, que expôs seus filhos gêmeos ao perigo, apesar de ter ele profetizado que ambos, Luperco e Galo, morreriam no campo de batalha (89-98); e de Cínara que, quando enfrentara dificuldades para dar à luz, ele aconselhara a fazer um voto a Juno, resolvendo-se os problemas (99-102). ${ }^{26}$

26 D. Paganelli diz em notas apostas à tradução do texto que a história de Árria e de seus dois filhos não é conhecida e que Cínara é uma personagem ignorada (Properce, 1970, p. 132, n. 2 e 4). Léon Herrmann, porém, em seu artigo intitulado "Horace adversaire de Properce" (Herrmann, 1933, p. 281-92), propõe uma hipótese interessante para dirimir 
Depois de ter falado dos filhos de Árria e de Cínara, Horos faz uma pausa e introduz no texto um elogio à astrologia, superior em tudo, segundo suas palavras, ao oráculo de Júpiter Amon, existente na Líbia, à aruspicina, à interpretação do vôo das aves, à magia das sombras dos mortos e até mesmo às profecias pronunciadas pelos vates de Apolo, como Calcante (103-118). Quando se supunha, porém, que nesse momento revelações fantásticas seriam feitas, Horos passa a dizer a Propércio quem é Propércio (119-150). Estende-se numa longa exposição, em que apenas se refere a trivialidades. Diz que o poeta nasceu na Úmbria, que perdeu o pai na infância, que foi espoliado de seus bens, que se dedicou à poesia desde a primeira juventude e que, por proibição de Apolo, não deve ocupar-se com negócios do forum, devendo, ao contrário, consagrar-se à elegia - fallax opus! - e ao amor.

Apenas nos últimos versos, possivelmente para impressionar o interlocutor, falando de coisas futuras e não do passado, Horos aconselha o "poeta", numa lin-

a questão. Para ele, Luperco e Galo são tios maternos de Propércio, mortos na guerra da Perúsia. $\mathrm{O}$ autor fundamenta a hipótese baseando-se nos dois epigramas finais do Cynthia Monobiblos (Prop. I, 21 e 22), considerados como a "assinatura poética" de Propércio. No primeiro epigrama, aparecem, com efeito, como personagens, dois soldados que haviam participado da guerra; um deles, moribundo, chamando-se a si próprio de Galo, se dirige ao outro que, aparentemente, fugia do campo de batalha; aconselha-o a salvarse "para alegrar os pais e a irmã" e faz referências a seus próprios ossos que ficarão dispersos pelos montes da Etrúria. No segundo epigrama, o poeta assume o discurso poético, refere-se à Perúsia, considerando-a o "túmulo da pátria" e fala dos ossos de seu "parente próximo", abandonados na Etrúria. Léon Herrmann aproxima os três poemas e procura mostrar que um fio condutor os une. Para ele, o Gallus da elegia IV, 1 é o mesmo da elegia I, 21; quanto ao soldado moribundo, seria provavelmente Lupercus, irmão de Gallus, uma vez que Propércio, ao referir-se a seus ossos e ao insistir, na elegia I, 22, na questão dos ossos de um parente, abandonados na poeira da Etrúria, estaria provavelmente homenageando um soldado morto, originário de sua família. A idéia de que ambos seriam irmãos desfaz a dúvida que poderia ocorrer na interpretação da referência feita pelo soldado moribundo aos pais e à irmã, quando não se sabe, ao certo, se ele estaria mencionando os pais e a irmã do companheiro ou seus próprios parentes. A admitir-se que Galo e Luperco sejam tios maternos do poeta, Árria seria sua avó e a irmã referida seria provavelmente sua própria mãe. Quanto a Cínara, Léon Herrmann a considera como antiga amante de Horácio que, posteriormente, ter-se-ia ligado a Propércio. As hipóteses de Herrmann procuram justificar as alusões contidas no monólogo de Horos. Se as considerarmos válidas, o adivinho estaria contando a "Propércio" coisas passadas, ocorridas com o próprio poeta ou com sua família, mais que conhecidas, certamente, não havendo, portanto, nenhum mérito extraordinário em tais "revelações". 
guagem bastante simbólica, a temer "o dorso sinistro do caranguejo de oito patas" (150). Refere-se, provavelmente, à constelação zodiacal que preside o mês de julho - época das febres e das epidemias, já mencionada em II, 28, 3-4 -, mas não esclarece a razão por que o faz. Talvez porque todos temessem as insídias do verão.

Essa elegia confirma a idéia de que Propércio trabalha em seus textos com uma ironia inteligente e velada, quando aborda assuntos encarados com seriedade pelos romanos, mas vistos com muitas restrições pelos poetas elegíacos. Apresentando um astrólogo "respeitável", oriundo de estirpe conhecida, o poeta parece desejar desacreditar a velha prática divinatória, "brincando" com ela. Nos dois monólogos, quem vê o futuro é "Propércio" e não Horos. O adivinho tece muitas considerações sobre a astrologia, mas se limita a falar do passado, de fatos sabidos. O poeta, conhecendo a falibilidade da crença romana, mostra que "ver" o futuro não é consultar uma esfera de bronze ou interpretar a mensagem oculta dos astros: é traçar um plano de trabalho e procurar executá-lo.

Resta uma última palavra sobre a posição irônica de Propércio em relação a questões nacionalistas como as conquistas e a guerra. ${ }^{27}$

A história romana, desde seus primórdios, foi ponteada de guerras e conquistas, graças às quais a pequena aldeia de pastores fundada às margens do Tibre se transformou na sede de um dos maiores impérios que o mudo conheceu. A época em que Propércio viveu foi a da consolidação desse império nas mãos de Augusto. $\mathrm{O}$ poeta, entretanto, muito embora seja considerado como um daqueles que participaram ativamente do grupo de Mecenas, encarregado de promover, pela poesia, a divulgação dos feitos do imperador, participando da política publicitária e promovendo a propaganda, vê, em geral, as guerras e conquistas como algo que lhe escapa à compreensão e ao interesse e as trata de forma irônica e galhofeira.

A primeira referência às guerras se encontra na elegia I, 6 , um bilhete poético endereçado ao mesmo Tulo ${ }^{28}$ mencionado em I, 1 . Nessa elegia ele se dirige ao suposto amigo, recusando-se a acompanhá-lo numa viagem à Grécia e ao Oriente. O motivo da recusa? O amor, a impossibilidade de deixar a amada e a falta de aptidão para os afazeres militares.

Assim se expressa ele no poema:

27 Para maiores detalhes sobre o assunto, ver Cardoso, 1998, p. 73-82.

28 Provavelmente se trata de um sobrinho do cônsul Volcácio Tulo, que se notabilizou por seus feitos. 
Tu patrui meritas conare anteire securis

et uetera oblitis iura refer sociis;

nam tua non aetas umquam cessauit amori, semper et armatae cura fuit patriae;

et tibi non umquam nostros puer iste labores

adferat et lacrimis omnia nota meis.

Me sine, quem semper uoluit fortuna iacere,

hanc animam extremae reddere nequitiae.

Multi longinquo periere in amore libenter,

in quorum numero me quoque terra tegat.

Non ego sum laudi, non natus idoneus armis;

hanc me militiam fata subire uolunt (I, 6, 19-30)

Quanto a ti, procura ultrapassar as honras consulares de teu tio

e leva as antigas leis aos aliados esquecidos;

pois que tua juventude nunca se dobrou ao amor

e tua única preocupação sempre foi para com as armas da pátria;

que o deus-menino nunca te traga sofrimentos como os meus

e nada do que é o motivo de minhas lágrimas.

Deixa-me, a mim que a sorte sempre quis abater,

entregar o meu espírito à extrema devassidão.

São muitos os que morreram livremente por sua paixão duradoura:

que a terra me cubra no meio deles.

Não nasci para a glória, não nasci capacitado para as armas.

Os destinos querem que eu me submeta a uma outra milícia.

As duas últimas elegias do livro I, muito curtas, relacionadas uma com a outra e consideradas como a "assinatura" do poeta, são uma alusão direta às legiões de Otávio, na Etrúria, e um repúdio à guerra da Perúsia, que vitimou tantos romanos (I, 21, 7-8).

No livro II, entretanto, a posição do poeta parece modificar-se. Na primeira elegia, embora ele se dirija a Mecenas afirmando que sua fonte de inspiração continua a ser a amada, diz que, se os destinos lhe permitissem escrever sobre guerras, cantaria as batalhas levadas a termo pelo César em companhia de Mecenas, as lutas travadas em Módena e Filipos, na Sicília, na Etrúria, em Rodes e em Ácio. 
Só não se pode falar em incoerência incompreensível porque o poeta até então não chegara a cantar tais eventos bélicos. E ele se justifica, fazendo uso daquela ironia brincalhona e já tão conhecida:

Nauita de uentis, de tauris narrat arator enumerat miles uulnera, pastor ovis, nos contra angusto uersantis proelia lecto; qua pote quisque, in ea conterat arte diem.

Laus in amore mori (II, 1, 41-45)

O marinheiro fala dos ventos; o lavrador, dos touros; o soldado conta seus ferimentos; o pastor, suas ovelhas.

$\mathrm{Eu}$, as batalhas travadas no leito estreito: que cada um passe seus dias segundo a arte que conhece.

É uma glória morrer durante um ato de amor!

Mais adiante, nas elegias II, 14 e II, 15, dois dos poucos poemas em que o "eu-poético" diz estar feliz e sentir-se realizado em sua paixão, ele volta a brincar com a questão das guerras. Na II, 14, após comparar sua alegria com a de Agamêmnon, ao vencer Tróia, refere-se à sua vitória pessoal, no leito da amada, cotejando-a com feitos bélicos realizados por romanos:

Haec mihi deuictis potior uictoria Parthis,

haec spolia, haec reges, haec mihi currus erunt (II, 14, 23-24)

Para mim essa vitória foi maior do que se tivesse sido sobre os partos:

ela será o meu espólio, ela será meus reis, ela será meus carros!

Na II, 15, após falar novamente de uma noite de intenso amor, acrescenta:

Qualem si cuncti cuperent decurrere uita et pressi multo membra iacere mero, non ferrum crudele neque esset bellica nauis nec nostra Actiacum uerteret ossa mare nec totiens propriis circum oppugnata triumphi lassa foret crinis soluere Roma suos.

Haec certe merito poterunt laudare minores laeserunt nullos pocula nostra deos (II, 15, 41-48) 
Se todos desejassem passar a vida assim,

e deitar com os membros entorpecidos por muito vinho,

não haveria armas cruéis nem navios de guerra

e o mar de Ácio não revolveria nossos ossos.

E Roma, cansada, oprimida por seus próprios triunfos,

não haveria de desatar seus cabelos, tantas vezes.

Isto os mais jovens, ao certo, poderão louvar com razão:

nossas taças jamais ofenderam os deuses.

É um manifesto de paz ou simplesmente uma brincadeira irônica de Propércio? Fica a pergunta para ser respondida.

No livro III, chama-nos ainda a atenção a elegia III, 9. O "eu-poético"se dirige novamente a Mecenas fazendo-lhe agora uma pergunta direta, conquanto figurada:

Quid me scribendi tam uastum mittis in aequor? (III, 9, 3)

Por que me envias ao tão vasto mar da arte de escrever?

Em seguida, depois de justificar-se dizendo que "as grandes velas não se adaptam" a seu barquinho - expressão que evoca as palavras de Apolo em III, 3, 22-24 -, o poeta faz uma reflexão sobre as diferenças que existem entre os homens e afirma que sua embarcação não foi feita para o alto mar e as vagas (III, 9, 35), que ele não celebrará as guerras e se contentará em causar prazer como Calímaco e em cantar como Filetas (III, 9, 43-44). Mas depois dessas palavras, o poeta acrescenta: se Mecenas lhe servir de guia ele cantará não só feitos épicos mitológicos, mas também guerras romanas, tais como a vitória sobre os partos, a campanha de Pelusa e a batalha de Ácio! Justamente o que antes havia sido condenado.

A promessa do poeta parece que vai ser cumprida quando, na elegia IV, 6, ele faz aparentemente o elogio à vitória de Ácio. E nós nos defrontamos com mais um enigma a ser decifrado.

Colocada estrategicamente no meio do livro, como a servir de clímax da obra, e inspirada no "Hino a Apolo" de Calímaco, a elegia IV, 6 é bastante original e merece uma análise cuidadosa tanto por sua forma de composição como pelo que nela é dito.

O poema, retoricamente, se divide em três partes. No exórdio (IV, 6, 1-14) encontramos a figura de um "eu" personalizado, caracterizado como um poeta- 
sacerdote que oferece um sacrifício. Algumas das palavras e expressões empregadas nos dois primeiros versos, tais como sacra, uates, ora fauentia, sacris, cadat, icta iunenca, focos, contribuem para criar uma atmosfera religiosa e misteriosa. Depois de haver aproximado a poesia alexandrina e aquela que florescia em Roma, comparando as tabuinhas romanas com os loureiros de Filetas e mencionando a água de Calímaco, empregada em abluções rituais, o costum e o incenso, o poeta-sacerdote invoca Calíope e lhe apresenta o assunto do poema: celebrará o templo de Apolo escrevendo versos em honra de Augusto.

Inicia-se, então, a narração propriamente dita. Há uma rápida descrição do local onde as esquadras de Otávio e Marco Antônio se confrontariam e a narrativa do primeiro encontro dos dois próceres (IV, 6, 15-24). Nesse momento, porém, quando se esperava a continuação da narrativa, o poeta a interrompe e nela introduz a figura de Apolo, que se une à de Otávio para lutar a seu lado. À descrição pormenorizada do deus segue-se a reprodução do longo discurso que ele dirige ao César, exaltando-lhe as virtudes e a causa pela qual está lutando. As flechas de Apolo e a lança de Augusto decidem a batalha. Cleópatra é vencida e Júlio César, do alto do céu, reconhece o valor de "seu sangue". Tritão o aplaude, bem como as demais divindades marinhas. A narração chega ao fim (IV, 6, 25-68).

O poeta-sacerdote suspende o canto e dá início à peroração. Cansado de celebrar guerras, ele invoca Apolo para que o deus deponha as armas e tome a lira para os plácidos coros (IV, 6, 70). A paz se instala e o poeta fala de seu desejo: que os convidados entrem no bosque sagrado, que as rosas acariciantes flutuem pelos copos, que o falerno corra e o açafrão banhe os cabelos.

Os doze versos finais da elegia são bastante curiosos; o poeta almeja que a musa excite o talento dos poetas bêbados (potis poetis - IV, 6, 75) e invoca Baco que, segundo ele, jamais deixa Febo estéril. Graças a Baco os poetas poderiam cantar a guerra contra os sicambros da qual Augusto se ocupava naquele momento e os futuros feitos do imperador, sobretudo suas vitórias sobre os partos. O poeta-sacerdote passaria então a noite, com sua taça na mão, e receberia em seu vinho os primeiros raios do sol. ${ }^{29}$

Com essa bela imagem a elegia se encerra, propondo-nos uma interpretação para a qual apresentamos uma hipótese.

29 Sic noctem patera, sic ducam carmine, donec/ iniciat radios in mea uina dies (IV,6,85-86). 
Já falamos que Propércio foi sempre considerado um poeta contraditório e que suas contradições fazem parte do jogo elegíaco, mostrando não raro sua verve irônica e brincalhona. Lendo-se a elegia IV, 6, uma das primeiras questões que se pode levantar diz respeito exatamente à aparente contradição que existe entre o tratamento do assunto do poema e o conteúdo de textos anteriores.

E difícil admitir que possa obedecer às ordens de Mecenas e cantar a vitória de Augusto o mesmo jovem que condenou a guerra da Perúsia em I, 21 e I, 22, que apenas almejou vitórias no leito da amada, que mais de uma vez lamentou a batalha de Ácio e que desejou a morte aos que preferem a guerra ao amor.

Como explicar a mudança?

A explicação se encontra, supomos, na interpretação de duas alegorias criadas pelo poeta e apresentadas no texto. A primeira consiste na colocação da figura de Apolo junto à de Augusto. $\mathrm{O}$ deus da poesia e da beleza se transfigura numa espécie de deus da guerra que exalta Augusto, anima a batalha e define a vitória. A presença do deus transforma o fato histórico num "acontecimento mítico" que pode ser cantado sem que se louve obrigatoriamente o sucesso das armas. $\mathrm{O}$ que se celebra não é uma batalha real; é uma fábula mitológica, construída à feição das que foram compostas pelos poetas alexandrinos. Além do mais, o elogio ao imperador guerreiro não é feito pelo poeta e, sim, por Apolo.

A segunda alegoria é ainda mais sutil. Para que o poeta possa celebrar a guerra, mesmo aquela que se constrói com elementos mitológicos, é preciso que ele seja ajudado não só pelo deus da poesia, mas também por Baco. Que a Musa excite o talento dos poetas ébrios. ${ }^{30}$ É preciso que ele beba durante toda uma noite e receba em sua taça os primeiros raios do sol misturados ao vinho. É necessário que a comunhão se opere e que o poeta esteja pleno de Baco para receber o espírito de Apolo e cantar a guerra ou, talvez, para esquecer seu canto.

Com essa imagem Propércio termina a elegia famosa, estendendo-a diante de nós como um painel - um painel polivalente, que permite várias leituras e que, por apresentar-se, numa das visões que suscita, como uma junção de alegorias irônicas, provoca o sorriso cúmplice do leitor.

Propércio, que já tratara o amor, a doença e a morte com ironia e que brincara com os deuses e com as práticas sagradas, leva para o campo do riso aquilo que fazia o orgulho do romano: sua capacidade de lutar e de vencer.

30 Ingenium potis irritet Musa poetis (IV,6,75). 
Define-se, portanto, o humor de Propércio: para expressá-lo convenientemente, o poeta se valeu dos recursos que lhe foram oferecidos pelas possibilidades do "jogo elegíaco".

\section{REFERÊNCIAS BibliográFICAS}

Allison, J. W. Propertius, 4, 7, 94. American Journal of Philology. 101. p. 170-173, 1980.

Boucher, Jean-Paul. Études sur Properce. Problèmes d'inspiration et d'art. 2e. éd. Paris: E. De Boccard, 1980.

CARDOSO, Zelia de A. "A representação da mulher na literatura latina". In: FunARI, P. P. e outros (Org.). Amor, desejo e poder na Antigüidade. Campinas: Editora Unicamp, 2003. . As elegias de Propércio: temática e composição. Tese de Livre-Docência. São Paulo: USP, 1984.

. "Histoire et mythe dans les élégies de Properce". In: Bouvier, D. et Calame,

C. (édit). Philosophes et historiens anciens face aux mythes. Études de Lettres 2.

Revue de la Faculte des Lettres de l'Université de Lausanne. p. 73-82, 1998.

. "Propércio e a adivinhação: ironia e crítica". In: Primeras Jornadas de Estúdios Clásicos. Montevideo, Facultad de Humanidades y Ciências de la Educación. Universidad de la República. 1995. p. 140-3.

. Propércio e a leitura dos sinais divinatórios. Classica. 4. p. 163-181, 1991.

Ernout, A. \& Thomas, F. Syntaxe latine. Paris: Klincksieck, 1953.

Frazer, J. G. The golden bough - a study in magic and religion (abridged edition). London: McMillan \& Co., 1933.

Grimal, P. L'amour à Rome. Paris: Hachette, 1963.

Herrmann, León. Horace adversaire de Properce. REA 35. p. 281-92, 1933.

Paganelli, D. Ver Properce. Élégies. Texte ét. et trad. par D. Paganelli. 4e. tir. Paris: Les Belles Lettres, 1970.

Patin, M. Études sur la poésie latine. 4e. éd. Paris: Hachette, 1900. Tome 1er.

Properce. Élégies. Texte ét. et trad. par D. Paganelli. 4e. tir. Paris: Les Belles Lettres, 1970.

Rostagni, Augusto. La letteratura di Roma repubblicana ed augustea. Bologna: Licinio Cappelli Editore, 1939. 
VeYne, Paul. A elegia erótica romana. Trad. de M. M. Nascimento e M. G. S. Nascimento. São Paulo: Brasiliense, 1985.

CARDOSO, Zelia de Almeida. Irony and humour in Properce's elegies.

ABSTRACT: We are trying to show some traces of humour on Properce's elegies in this article. They are chiefly revealed due to the ironic treatment sometimes given to love, illness, death, religion and nationalism. Irony, considered as one of the characteristics of the elegiac gender, confirms the hypothesis that the elegy is a poem elaborated according to established aesthetic rules.

KEY WORDS: Properce; elegies; irony; humour. 